\title{
WEAK SOLUTIONS FOR CAPUTO-PETTIS FRACTIONAL $q$-DIFFERENCE INCLUSIONS
}

\section{SAÏD ABbas, BASHIR AHMAD, MOUfFAK BENCHOHRA AND SOTIRIS NTOUYAS}

Abstract. This article deals with some existence of weak solutions for a class of Caputo fractional $q$-difference inclusions and a coupled system of Caputo fractional $q$-difference inclusions by using the set-valued analysis, and Mönch's fixed point theorem associated with the technique of measure of weak noncompactness. Two illustrative examples are given in the end.

Mathematics subject classification (2010): 26A33.

Keywords and phrases: Pettis $q$-difference inclusion, Caputo fractional derivative, measure of weak noncompactness, coupled system, weak solution, fixed point.

\section{REFERENCES}

[1] S. AbBas, M. Benchohra, A. Als Aedi And Y. Zhou, Weak solutions for partial random Hadamard fractional integral equations with multiple delay, Discrete Dyn. Nature Soc., Vol. 2017 (2017), Article ID 8607946, 7 pages.

[2] S. Abbas, M. Benchohra, A. Alsaedi And Y. Zhou, Weak solusions for a coupled system of Pettis-Hadamard fractional differential equations, Adv. Difference Equ. 2017: 332, 11 pp, doi: 10.1186/s13662-017-1391-z.

[3] S. Abbas, M. Benchohra And J.R. Graef, Coupled systems of Hilfer fractional differential inclusions in Banach Spaces, Comm. Pure Appl. Anal., 17 (6) (2018), 2479-2493.

[4] S. Abbas, M. Benchohra, J.R. Graef and J. Henderson, Implicit Fractional Differential and Integral Equations: Existence and Stability, De Gruyter, Berlin, 2018.

[5] S. AbBas, M. Benchohra, J.R. Graef And J.E. LAZREG, Implicit Hadamard fractional differential equations with impulses under weak topologies, Dyn. Cont., Dis. Impuls. Syst. Series A: Math. Anal., 26 (2019), 89-112.

[6] R. Agarwal, Certain fractional $q$-integrals and q-derivatives, Proc. Camb. Philos. Soc. 66 (1969), 365-370.

[7] B. Ahmad, S.K. NTOUYAs AND I.K. PuRnARAs, Existence results for nonlocal boundary value problems of nonlinear fractional q-difference equations, Adv. Difference Equ. 2012, 2012:140.

[8] B. Ahmad, J.J. Nieto, A. Als Aedi, H. Al-Hutami, Existence of solutions for nonlinear fractional $q$-difference integral equations with two fractional orders and nonlocal four-point boundary conditions, J. Franklin Inst. 351 (2014), 2890-2909.

[9] B. Ahmad, S.K. Ntouyas, J. Tariboon, Quantum Calculus. New Concepts, Impulsive IVPs and BVPs, Inequalities, Trends in Abstract and Applied Analysis, 4, World Scientific Publishing Co. Pte. Ltd., Hackensack, NJ, 2016.

[10] B. Ahmad, S. Etemad, M. Ettefagh, Sh. Rezapour, On the existence of solutions for fractional $q$-difference inclusions with q-anti-periodic boundary conditions, Bull. Math. Soc. Sci. Math. Roumanie 59 (107) No.2 (2016) 119-134.

[11] D. BUGAJEWS KI AND S. SzUFLA, Kneser's theorem for weak solutions of the Darboux problem in a Banach space, Nonlinear Anal. 20 (2) (1993), 169-173.

[12] F.S. DE BLASI, On the property of the unit sphere in a Banach space, Bull. Math. Soc. Sci. Math. R.S. Roumanie 21 (1977), 259-262.

[13] S. ETEMAD, S.K. NTOUYAS AND B. AhMAD, Existence theory for a fractional q-integro-difference equation with q-integral boundary conditions of different orders, Mathematics 7659 (2019), 1-15. 
[14] J.R. GRAEF, L. Kong, Positive solutions for a class of higher order boundary value problems with fractional q-derivatives, Appl. Math. Comput. 218 (2012) 9682-9689.

[15] D. Guo, V. Lakshmikantham and X. Liu, Nonlinear Integral Equations in Abstract Spaces, Kluwer Academic Publishers, Dordrecht, 1996.

[16] H.F. Huo, W.T. LI, Oscillation criteria for certain two-dimensional differential systems, Int. J. Appl. Math. 6 (2001), 253-261.

[17] V. KaC And P. Cheung, Quantum Calculus, Springer, New York, 2002.

[18] A.A. Kilbas, H. M. SRivastava And JuAn J. Trujillo, Theory and Applications of Fractional Differential Equations, North-Holland Mathematics Studies, 204. Elsevier Science B.V., Amsterdam, 2006.

[19] J. A. Tenreiro Machado, V. Kiryakova, The chronicles of fractional calculus, Fract. Calc. Appl. Anal. 20 (2017), 307-336.

[20] D. O'REgan, R. Precup, Fixed point theorems for set-valued maps and existence principles for integral inclusions, J. Mth. Anal. Appl. 245 (2000), 594-612.

[21] D. O'REGAN, Fixed point theory for weakly sequentially continuous mapping, Math. Comput. Model. 27 (5) (1998), 1-14.

[22] B. J. PetTIS, On integration in vector spaces, Trans. Amer. Math. Soc. 44 (1938), 277-304.

[23] Y.N. RAFFOUL, Classification of positive solutions of nonlinear systems of Volterra integral equations, Ann. Funct. Anal. 2 (2011), 34-41.

[24] P.M. Rajkovic, S.D. Marinkovic AND M.S. Stankovic, On q-analogues of Caputo derivative and Mittag-Leffler function, Fract. Calc. Appl. Anal. 10 (2007), 359-373.

[25] V. E. TARasov, Fractional Dynamics: Application of Fractional Calculus to Dynamics of Particles, Fields and Media, Springer, Heidelberg; Higher Education Press, Beijing, 2010.

[26] Y. Zhou, Basic Theory of Fractional Differential Equations, World Scientific, Singapore, 2014. 